\title{
Spatial and Temporal Stability of Major and Trace Element Leaching in Urban Stormwater Sediments
}

\author{
Clémentine Drapeau1, Cécile Delolme², Vincent Chatain², Mathieu Gautier², Denise Blanc², \\ Mostafa Benzaazoua ${ }^{2,3}$, Laurent Lassabatère ${ }^{1^{*}}$
}

${ }^{1}$ Université de Lyon, ENTPE, LEHNA (Laboratoire d’Ecologie des Hydro-systèmes Naturels et Anthropisés), Vaulx-en-Velin, France

${ }^{2}$ Université de Lyon, INSA Lyon, DEEP (Déchets Eaux Environnement Pollutions), Villeurbanne, France

${ }^{3}$ Université du Québec en Abitibi-Témiscamingue, Rouyn-Noranda, Québec, Canada

Email: *laurent.lassabatere@entpe.fr

How to cite this paper: Drapeau, C., Delolme, C., Chatain, V., Gautier, M., Blanc, D., Benzaazoua, M. and Lassabatère, L. (2017) Spatial and Temporal Stability of Major and Trace Element Leaching in Urban Stormwater Sediments. Open Journal of Soil Science, 7, 347-365.

https://doi.org/10.4236/ojss.2017.711025

Received: October 5, 2017

Accepted: November 27, 2017

Published: November 30, 2017

Copyright $(9) 2017$ by authors and Scientific Research Publishing Inc. This work is licensed under the Creative Commons Attribution International License (CC BY 4.0).

http://creativecommons.org/licenses/by/4.0/

\begin{abstract}
Urban sediment generated by stormwater management techniques are highly contaminated with various trace elements. The characterization of trace element speciation and mobility are critical information to improve environmental risk assessment. This study investigates the spatial and temporal variability of major and trace element release from a sedimentary layer in Django Reinhart stormwater infiltration basin (Chassieu, eastern suburbs of Lyon, France). Sampling was conducted for 3 zones and two dates. Chemical characterization was performed (X-Ray diffraction, ICP-AES). The samples were submitted to Acid Neutralization Capacity \& Base Neutralization Capacity ANC-BNC tests, according to European standard 14429 (AFNOR, 2015). Solid matrices were mixed with acid or basic solutions and physicochemical parameters and major and trace element release (i.e. $\mathrm{Al}, \mathrm{Ca}, \mathrm{Fe}, \mathrm{P}, \mathrm{S}, \mathrm{Si}, \mathrm{Cu}, \mathrm{Zn}$ and total carbon) were followed as a function of $\mathrm{pH}$. The results show that the urban sediment has no significant spatial and temporal variability with regards to element release. This observation is all the more surprising that the samples were collected in three contrasting zones regarding stormwater supply and hydric conditions. Element release follows the same trends as a function of $\mathrm{pH}$ with a bell-shaped solubilization curve exhibiting the highest solubility at extreme $\mathrm{pH}$ values. However, the samples showed slight differences concerning the release of major elements. Such differences are related to slight differences in total mineral contents (organic matter, carbonates...) and chemical composition of the sediments. The results show that despite the varying environmental conditions, the sediment chemical properties can be considered as very stable and uniform over space, dependent mainly on the local geochemical context and watershed characteristics. This study highlights
\end{abstract}


the strength and affluence of the information obtained by ANC-BNC tests on the release of major and trace metal elements by urban sediments and brings relevant information regarding the management of these sediments.

\section{Keywords}

Component, Urban Sediment, Element Release, Acid and Basic Neutralization Capacity

\section{Introduction}

Settlement and infiltration basins were developed to deal with the crucial issue of stormwater management. These devices are used to recharge groundwater and reduce direct discharges in wastewater sewage systems. Infiltration basins concentrate rainwater collected over watersheds of several hectares in small areas [1]. This concentration of fluxes explains why suspended solids carried by stormwater accumulate at the soil surface and form a sedimentary layer with high trace metal and organic compound contents [2] [3]. There are many studies on the composition and characterization of sedimentary layers accumulated in stormwater infiltration basins. These studies constitute a database on sediments contamination that points at the high contents of trace element (e.g. up to 2400 ppm of zinc, $500 \mathrm{ppm}$ of lead, $300 \mathrm{ppm}$ of chromium and copper) [2] [4]-[10]. To assess the risk of contamination of the subsoil and groundwater, the mobility of elements trapped in these sediments must be investigated [11] [12].

Within the framework of the French observatory for urban hydrology-SOERE URBIS [10], different studies were dedicated to the geochemical characterization of stormwater sediments and their pollutant-carrier solid phases. A large panel of analytical techniques was employed to characterize the sediments geochemical characteristics at both bulk and micro scales using XRD and SEM analysis [7] [8] [13]. These analyses gave information on the main pollutants-bearing solid phases (mineral and organic) and showed that the main mineral phases are related to the local geochemical context of the basin and should remain constant over time. Few SEM observations of anthropogenic and non-crystallized particles underline the presence of slag mineral particles composed of various alloys made of cupro aluminium with $\mathrm{Fe}, \mathrm{Ni}, \mathrm{Mn}, \mathrm{Fe}-\mathrm{Cr}-\mathrm{Ni}$ stainless steels or organic residues spread from tire abrasion, brake pads or road asphalt grains containing traces of $\mathrm{Zn}$ or $\mathrm{Cu}$ [13]. However, these measures and observations have often been conducted on samples taken at a single time and a single location in the infiltration system.

The solubility of trace metals depends on the mineral and organic phases they are bound to. Sequential extractions carried out on these different urban sediments [14] [15] showed that $\mathrm{Cu}$ was both under reducible and oxidable forms whereas $\mathrm{Zn}$ was both in exchangeable and reducible forms. In other studies, [16] showed that $\mathrm{Zn}$ and $\mathrm{Cu}$ were mainly associated to carbonate and organic matter 
fractions, in particular for the samples collected in calcareous environments (e.g. Django Reinhardt infiltration basin, Chassieu, East of Lyon). These approaches did not investigate the links between metal trace solubility and the specific dissolution of mineral or organic phases without any simultaneous monitoring of major elements mobility, mineral dissolution and trace element release, rendering impossible the identification of the mechanisms responsible for trace element release [17] [18]. Moreover, these results were produced with sediments sampled at a single time and often at a single location with the aim to conclude for the whole infiltration systems. However, the dependency of results on space and time may be questioned when asserting general chemical properties of these urban sediments are targeted.

The dissolution reactions that are responsible for the alteration of mineral phases and subsequent release of trace metals are mainly controlled by $\mathrm{pH}$. Acidity potential is one of the key factors for the dissolution of calcareous minerals and organic phases and thus for the release of major and trace elements [19] [20]. Similarly, alkalinity may alter organic matter and thus favour the release of associated major or trace metals. Acid Neutralization Capacity \& Base Neutralization Capacity ANC-BNC titrations are a promising tool for the quantification of phase alteration and subsequent pollutants release triggered by a source of protons (acidic condition) or a source of alkalinity (basic condition). ANC-BNC titrations have already been used for the quantification of pollutant release as a function of $\mathrm{pH}$ for several solid materials like wastes or construction materials [21] [22] [23] [24]. However, applications to urban sediments remain scarce; despite the potential utility of such a tool for the management of urban sediments.

This study focuses on the characterization of solid phase alteration and associated major and trace element release for stormwater sediment accumulated at the surface of an infiltration basin (experimental pilot) monitored within the framework of the French survey on urban sediments [13]. For this purpose, we carried out ANC-BNC titrations with the following objectives: i) address the question of space and time stability of phase alteration and trace element release, in relation to the functioning of the infiltration basin and its evolution with time, ii) link the release of trace element with majors and phase alteration to pinpoint the bearing phases. More precisely, ANC-BNC titration measurements were carried out on samples collected in Django Reinhardt infiltration basin at several locations in summer 2013 and spring 2015. The locations were chosen to sample the sediment at several distances from the stormwater entry, and therefore different hydraulic conditions. The analysis of all these results will allow the comparison of the quality and robustness of two different sampling procedures: sampling one location once versus sampling several locations at several times.

\section{Materials and Methods}

\subsection{Site Sampling}

The samples were collected in the Django Reinhardt infiltration basin which is 
located in Chassieu (East suburb of Lyon, France) and infiltrates the stormwater collected over an industrial catchment. The catchment and the infiltration basin have respective areas of 185 and 1.4 hectares [25]. An upstream settling basin allows for suspended solid sedimentation before routing the stormwater to the infiltration basin. The infiltration basin has been excavated in a heterogeneous glaciofluvial deposit [26] with a groundwater table located 13 meters underneath. A dredging of the upper layer in the basin was performed in 2007 after 10 years of operation [8]. Since then, a layer of several $\mathrm{cms}$ of suspended matter had settled at the surface [3], despite the upstream settling basin, and vegetation has grown [27]. Both basins were instrumented as part of sites monitored by the Field Observatory for Urban Water Management-Observatoire de Terrain en Hydrologie Urbaine-OTHU (http://www.graie.org/othu/). This observatory is part of the French Observatory for urban hydrology and unifies 12 research laboratories from Lyon (France) with expertise in climatology, hydrology, fluid mechanics, geography, soil sciences, chemistry, biology, microbiology, and social sciences to investigate a wide range of phenomena associated with urban drainage [28].

Three zones, corresponding to distinct hydraulic conditions, were investigated (Figure 1). Zone 1, $25 \mathrm{~cm}$ thick, is located at the stormwater entry and is always ponded. This zone corresponds to first place for the deposition of sediments when stormwater enters the basin. Zone 2, $8 \mathrm{~cm}$ thick, is often ponded with water since it is more easily reached by stormwater entering the infiltration basin. Zone 3,10 cm thick, is located at the upper part of the basin and is usually dry, but can be recovered suddenly by incoming stormwater. The zones are sorted by the distance to stormwater entry, from the most reachable (zone 1) to the least reachable (zone 3).

The first campaign of sample collection was conducted for three zones with different hydraulic conditions, in 2013. A second campaign was carried out in April 2015, in large zone around storm and urban water arrival. This area was

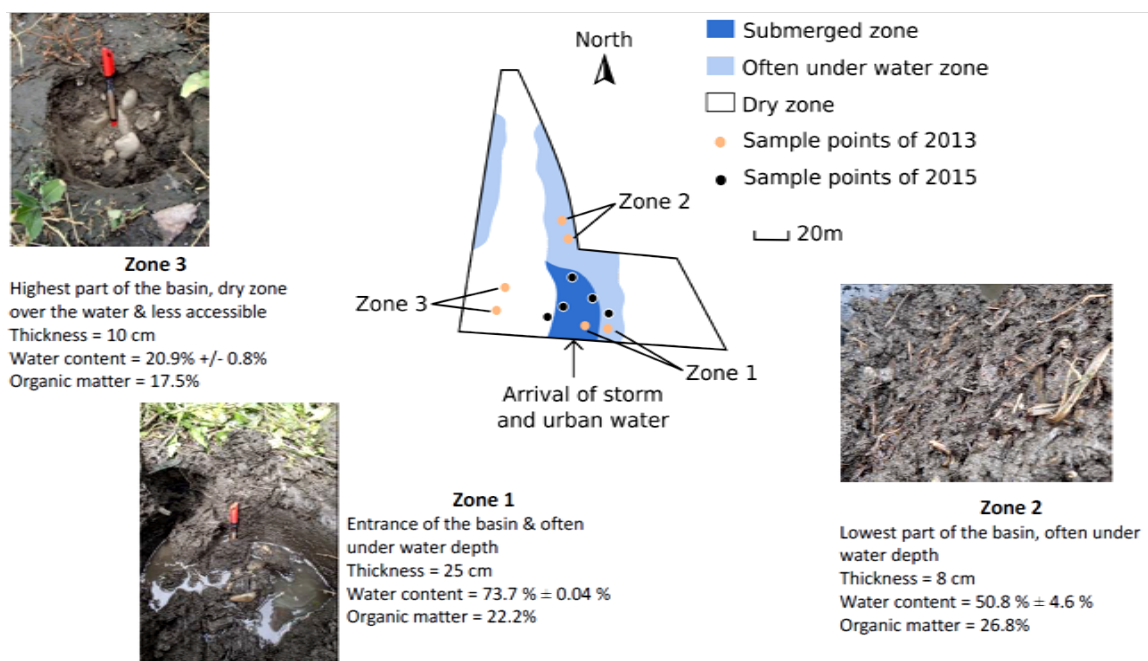

Figure 1. Areas sampled in 2013 (zones 1, 2 and 3) and 2015 (black points). 
considered as the best representative of major and trace element release. For each sample, the whole thickness of the sedimentary layer was collected. The coarse material (stones, roots...) were manually removed. Once collected, the samples were homogenized in the laboratory, lyophilized and stored at $4^{\circ} \mathrm{C}$ (Labconco FreeZone Freeze Dry Systems 4.5 Plus). Lyophilization aimed at ensuring the preservation of inorganic and organic phases. The samples were then submitted to ANC-BNC experiments. A semi-quantitative mineralogical characterization (X-Ray Diffraction) and elemental analysis (solid mineralization and determination of metal concentration by Induced Coupled Plasma-Atomic Emission Spectrometry-ICP-AES) were performed on samples collected in 2013.

\subsection{ANC-BNC Measurement and Related Analyses}

ANC-BNC titration characterizes the physicochemical stability and buffering capacity to acid-base aggression [22]. It was performed according to EN 14429: 2015 norm [29] developed by the European Committee for Standardization (Comité Européen de Normalisation-CEN). This method consists in mixing the same solid material with water after the addition of different quantities of acid or base. For our experiment, dry sediments were crushed and 1-mm-sieved before introduction into batch reactors containing pure water and several amounts of $\mathrm{HNO}_{3}$ or $\mathrm{KOH}(5 \mathrm{M})$ with a solid-liquid ratio of $10 \mathrm{~g} / \mathrm{L}$. Batch reactors were closed and agitated for 72 hours. At the end of experiments, the liquid samples were centrifugated for 20 minutes, and supernatants were filtered at $0.45 \mu \mathrm{m}$ before measurement of physicochemical parameters ( $\mathrm{pH}$, conductivity, redox potential), major and trace element contents (ICP-AES: Al, Ca, Fe, P, S, Si, $\mathrm{Cu}, \mathrm{Zn}$ ), and dissolved organic carbon content (TOC meter: ๑ Shimadzu, TOC model 5050A).

For all sediment samples, the number of batches was multiplied to depict ANC-BNC titration curves over a large range of $\mathrm{pH}$. For the samples collected in 2013, 27 measures (including 7 triplicates) were performed for zone 3, 21 measures (including 7 triplicates) for zone 2 and, finally, 22 measures (including 5 triplicates) for zone 1. For the samples collected in 2015, 64 measurements were carried out without any replicate, given the good reproducibility of experiments. To characterize $\mathrm{pH}$ buffering capacity, $\mathrm{pH}$ was plotted against the amount of acid or base introduced $\left(\right.$ eq_H $\mathrm{H}^{+}$). Note that Eq_ $\mathrm{H}^{+}$corresponds to the quantity of protons $\mathrm{H}^{+}$for $\mathrm{ANC}$ and the quantity of $\mathrm{OH}^{-}$multiplied by -1 for BNC. Conductivity and redox potential were plotted against $\mathrm{pH}$. Major and trace element release was characterized by plotting concentrations against $\mathrm{pH}$ instead of Eq_H $\mathrm{H}^{+}$, as suggested by [20].

\section{Results}

\subsection{Geochemical Characteristics of the Sediment}

The three samples collected in 2013 have similar element contents (Table 1). 
Element contents are quite typical of alumino-silicates with high contents of $\mathrm{Si}$, $\mathrm{Al}$ and also Fe. The high content of calcium is consistent with the high calcite contents (Table 2) and probably results from the geological backgrounds [30]. The significant amounts of phosphorus and sulfur (Table 1) may result from biological and geochemical processes, with a potential anthropic or even natural origin. Regarding trace elements, the high contents of $\mathrm{Zn}$ and $\mathrm{Cu}$ point at the contribution of anthropic activity and traffic [13].

The different samples of sediment exhibit also similar pattern regarding DRX measures. The mineral phases identified in the sediment layer are sorted as follow, by decreasing order: quartz, calcite, illite, albite, hornblende, chamosite, orthoclase, labradorite, pyrite, and rutile (Table 1). This mineral composition is consistent with the element contents. Optical and Scanning Electron Microscopic observations were performed to describe mineral and trace elementbearing phases. SEM analyses pointed at the occurrence of pyrite minerals with sizes in the order of dozens of micrometres (Figure 2). This mineral is part of the key factors for understanding buffer capacity, major and trace element release [17], and thus must be considered for ANC-BNC experiments.

Our findings are consistent with previous studies from French Observatory

Table 1. Major and trace element contents in the sediment collected in 2013.

\begin{tabular}{ccccccccc}
\hline & $\mathrm{Si}(\mathrm{g} / \mathrm{kg})$ & $\mathrm{Al}(\mathrm{g} / \mathrm{kg}) \mathrm{Ca}(\mathrm{g} / \mathrm{kg})$ & $\mathrm{Fe}(\mathrm{g} / \mathrm{kg})$ & $\mathrm{P}(\mathrm{g} / \mathrm{kg})$ & $\mathrm{S}(\mathrm{g} / \mathrm{kg})$ & $\mathrm{Zn}(\mathrm{mg} / \mathrm{kg}) \mathrm{Cu}(\mathrm{mg} / \mathrm{kg})$ \\
\hline Zone 1 & 201.4 & 21.2 & 54.3 & 16.5 & 1.2 & 7.9 & 2635.8 & 284.7 \\
Zone 2 & $209 / 5$ & 25.9 & 19.6 & 19.5 & 1.2 & 9.0 & 2413.3 & 298.0 \\
Zone 3 & 239.7 & 16.1 & 62.1 & 14.3 & 0.6 & 6.4 & 1555.5 & 225.8 \\
Mean & 216.9 & 21.1 & 45.3 & 16.8 & 1,0 & 7.8 & 2201.5 & 269.5 \\
Std & 20.2 & 04.9 & 22.6 & 2.6 & 0.35 & 1.3 & 570.4 & 38.43 \\
\hline
\end{tabular}

Table 2. Mineral phases characterization and contents (\% of dry mass).

\begin{tabular}{|c|c|c|c|c|c|c|}
\hline Mineral Phase & Formula & Zone 1 & Zone 2 & Zone 3 & Mean & Std \\
\hline Albite & $\mathrm{NaAlSi}_{3} \mathrm{O}_{8}$ & 5.89 & 6.35 & 6.2 & 6.15 & 0.23 \\
\hline Calcite & $\mathrm{CaCO}_{3}$ & 12.4 & 4.55 & 14.05 & 10.33 & 5.08 \\
\hline Chamosite & $\mathrm{Fe}_{2} \mathrm{Al}_{2} \mathrm{SiO}_{5}(\mathrm{OH})_{4}$ & 9 & 11 & 4.81 & 8.27 & 3.16 \\
\hline Hornblende & $(\mathrm{Ca}, \mathrm{Na}, \mathrm{K})_{2}\left(\mathrm{Mg}, \mathrm{Fe}^{2+}, \mathrm{Fe}^{3+}, \mathrm{Al}\right)^{5}\left[\mathrm{Si}_{6}(\mathrm{Al}, \mathrm{Si})_{2} \mathrm{O}_{22}\right](\mathrm{OH}, \mathrm{F})_{2}$ & 1.11 & 0.7 & 5 & 2.27 & 2.37 \\
\hline Illite & $\mathrm{K}_{0.6} \mathrm{Mg}_{0.25} \mathrm{Al}_{1.8} \mathrm{Al}_{0.5} \mathrm{Si}_{3.5} \mathrm{O}_{10}(\mathrm{OH})_{2}$ & 14 & 22 & 10 & 15.33 & 6.11 \\
\hline Labradorite & $\mathrm{NaAlSi}_{3} \mathrm{O}_{8}$ et $\mathrm{CaAl}_{2} \mathrm{Si}_{2} \mathrm{O}_{8}$ & 0.85 & 0.22 & 1.28 & 0.78 & 0.53 \\
\hline Magnétite & $\mathrm{Fe}_{3} \mathrm{O}_{4}$ & 0.12 & 0.1 & - & 0.11 & 0.01 \\
\hline Orthoclase & $\mathrm{KAlSi}_{3} \mathrm{O}_{8}$ & 4.3 & - & 3.35 & 3.83 & 0.67 \\
\hline Pyrite & $\mathrm{FeS}_{2}$ & - & - & 0.37 & 0.37 & - \\
\hline Quartz & $\mathrm{SiO}_{2}$ & 21.3 & 22.4 & 32 & 25.23 & 5.89 \\
\hline Rutile & $\mathrm{TiO}_{2}$ & 0.4 & 0.45 & 0.35 & 0.40 & 0.05 \\
\hline
\end{tabular}



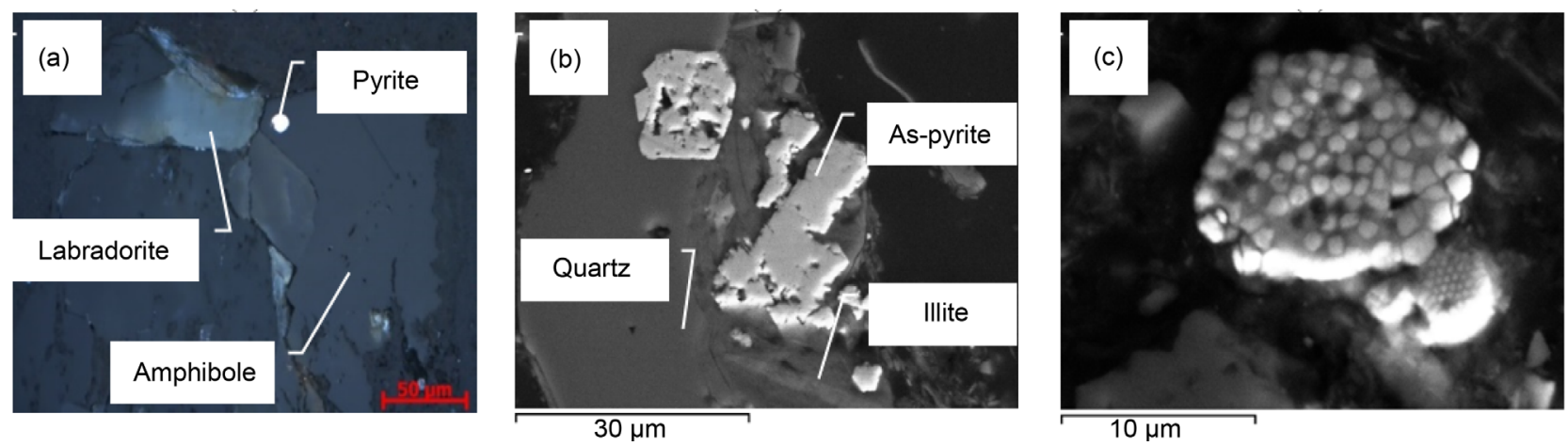

Figure 2. Reflectance microscopy image (a) and backscattered electron SEM microscopy images (b) and (c) showing minerals with arseniferous pyrite in zone 3 (b); and framboid pyrite zone 2 (c).

for urban hydrology-SOERE URBIS [14] [15]. Saulais et al. [31] studied the distribution of trace elements (e.g; $\mathrm{Cd}, \mathrm{Cu}$ and $\mathrm{Zn}$ ) between exchangeable, carbonate and organic matter fractions using selective sequential extraction techniques. Their findings show that $\mathrm{Zn}$ is mainly associated to carbonate and organic matter fractions. $\mathrm{Cd}$ and $\mathrm{Cu}$ vary with time and space and are bound to carbonate and organic matter fractions. For $\mathrm{Cu}$, the organic fraction constitutes more than $50 \%$ of the total content.

\subsection{Spatial Variability for Chemical Parameters and Major Release}

pH buffering capacity, conductivity (in log scale) and redox potential variations with $\mathrm{pH}$ are illustrated in Figure 3 for the three samples collected in 2013. The variation of these parameters with $\mathrm{pH}$ exhibits similar trends for the three samples. The buffer capacities at $\mathrm{pH} 6$ are of the same order for all these samples (Figure 3, pH). The buffering impact is stronger for zones 1 and 3 than zone 2. Indeed, for zones 1 and 3, the $\mathrm{pH}$ drop is more regular. For all samples, the conductivity is very high for extreme $\mathrm{pH}$ values. The conductivity reaches its minimum value around $\mathrm{pH}=7$, i.e. for the case of no addition of acid or base (Figure 3, Conductivity). The redox potential regularly decreases with increasing $\mathrm{pH}$ (base addition), with an amplification and a scattering of values around $\mathrm{pH}=7$ (Figure 3, Redox potential).

The different solutes concentrations versus $\mathrm{pH}$ are illustrated in Figure 5. The release of aluminium $(\mathrm{Al})$, iron $(\mathrm{Fe})$, copper $(\mathrm{Cu})$ and zinc $(\mathrm{Zn})$ follows a bellshaped curve (Figure 5). Their solubility is lower between $\mathrm{pH}=6$ and 8. It increases around $\mathrm{pH}=10$ before following a lower slope between $\mathrm{pH}=10$ and $\mathrm{pH}$ $=14$. Overall, the solubilized concentrations are lower in basic conditions in comparison with acidic conditions. The solubility of phosphorus (P), sulfur (S), silicon ( $\mathrm{Si}$ ) and organic carbon (Organic Carbon) is much less contrasted as a function of $\mathrm{pH}$ (Figure 5). Finally, the calcium (Ca) solubility raises for $\mathrm{pH}<6$ and reaches a maximum value in acidic conditions. Above $\mathrm{pH}=6$, calcium concentration remains stable between 50 and $100 \mathrm{mg} / \mathrm{L}$. 

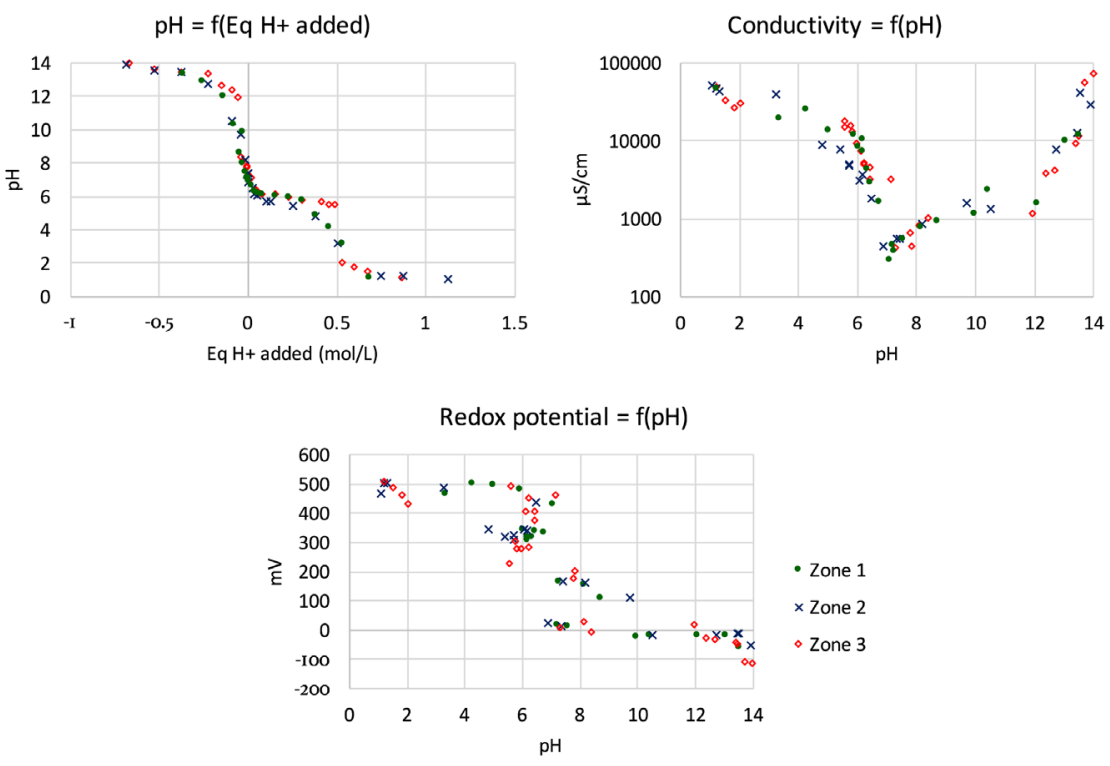

Figure 3. ANC-BNC measurements including $\mathrm{pH}$, conductivity and redox potential for the three zones in 2013.
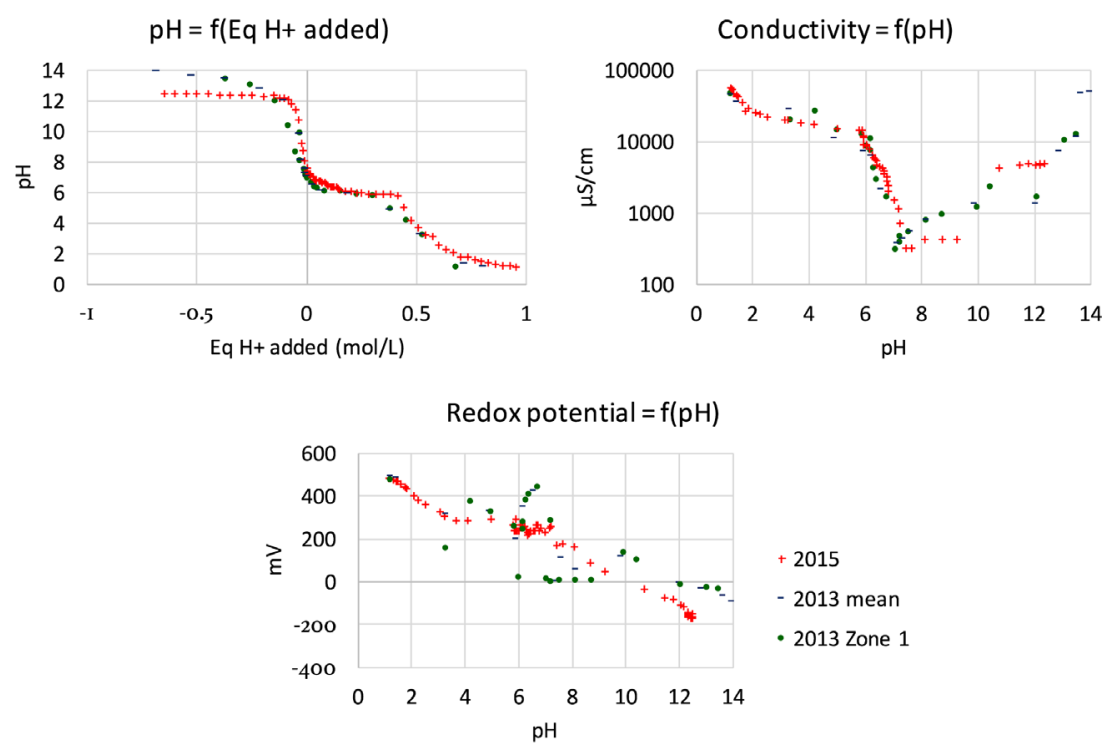

Figure 4. ANC-BNC measurements including $\mathrm{pH}$, conductivity and redox potential for 2013 (zone 1 and zone-averaged sample) and 2015 (zone 1).

\subsection{Temporal Variability for Chemical Parameters and Major Release}

Figure 4 compares the ANC-BNC results for the sample collected in 2015 (zone 1) with those collected in 2013 (zone 1 and zone-averaged data). The $\mathrm{pH}$ curves are very close, indicating no significant change with time (Figure $4, \mathrm{pH}$ ). In all cases, the buffering capacity remains located at $\mathrm{pH}=6$ and decreases with an addition of $0.4 \mathrm{M}$ of acid. The acidic asymptote $(\mathrm{pH}=1)$ is the same for both years. The basic asymptote is positioned at a higher $\mathrm{pH}$ for 2013 with $\mathrm{pH}$ values 

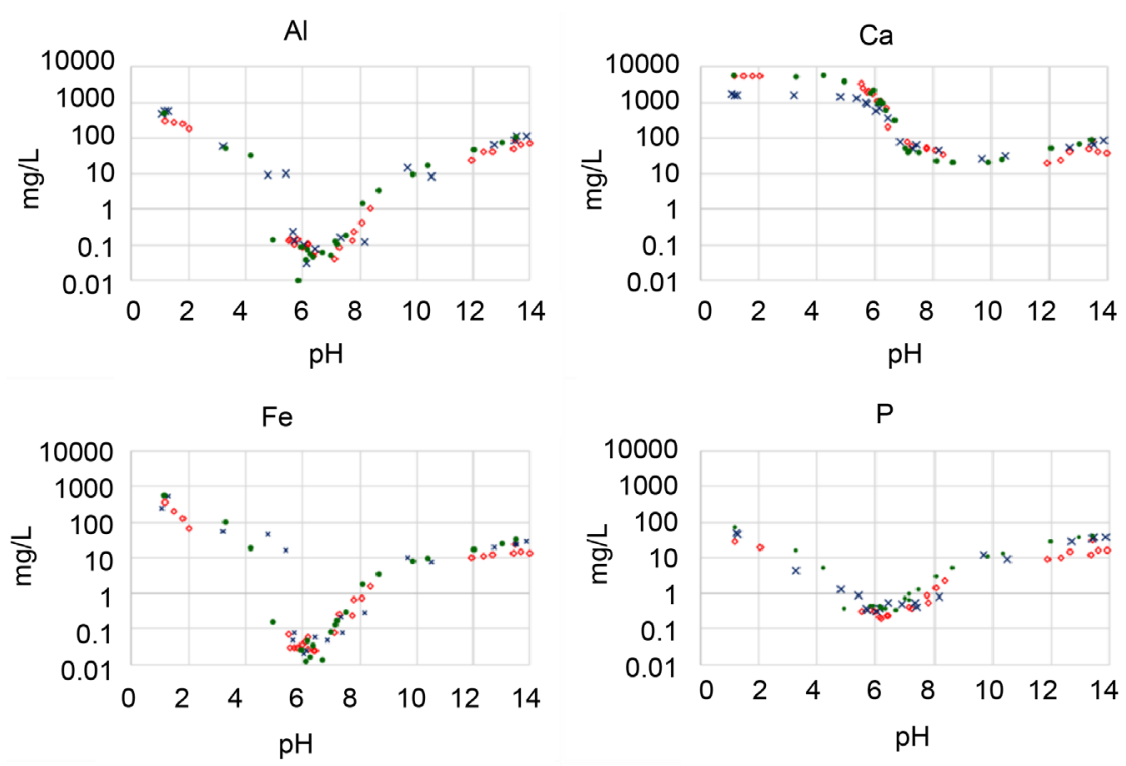

S

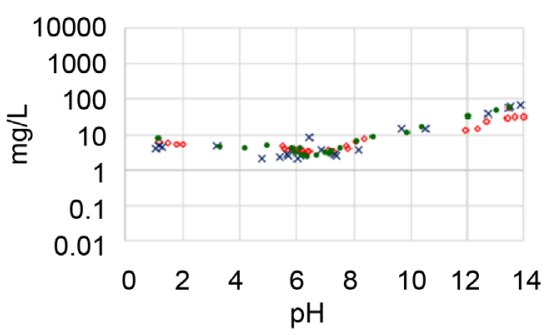

$\mathrm{Si}$
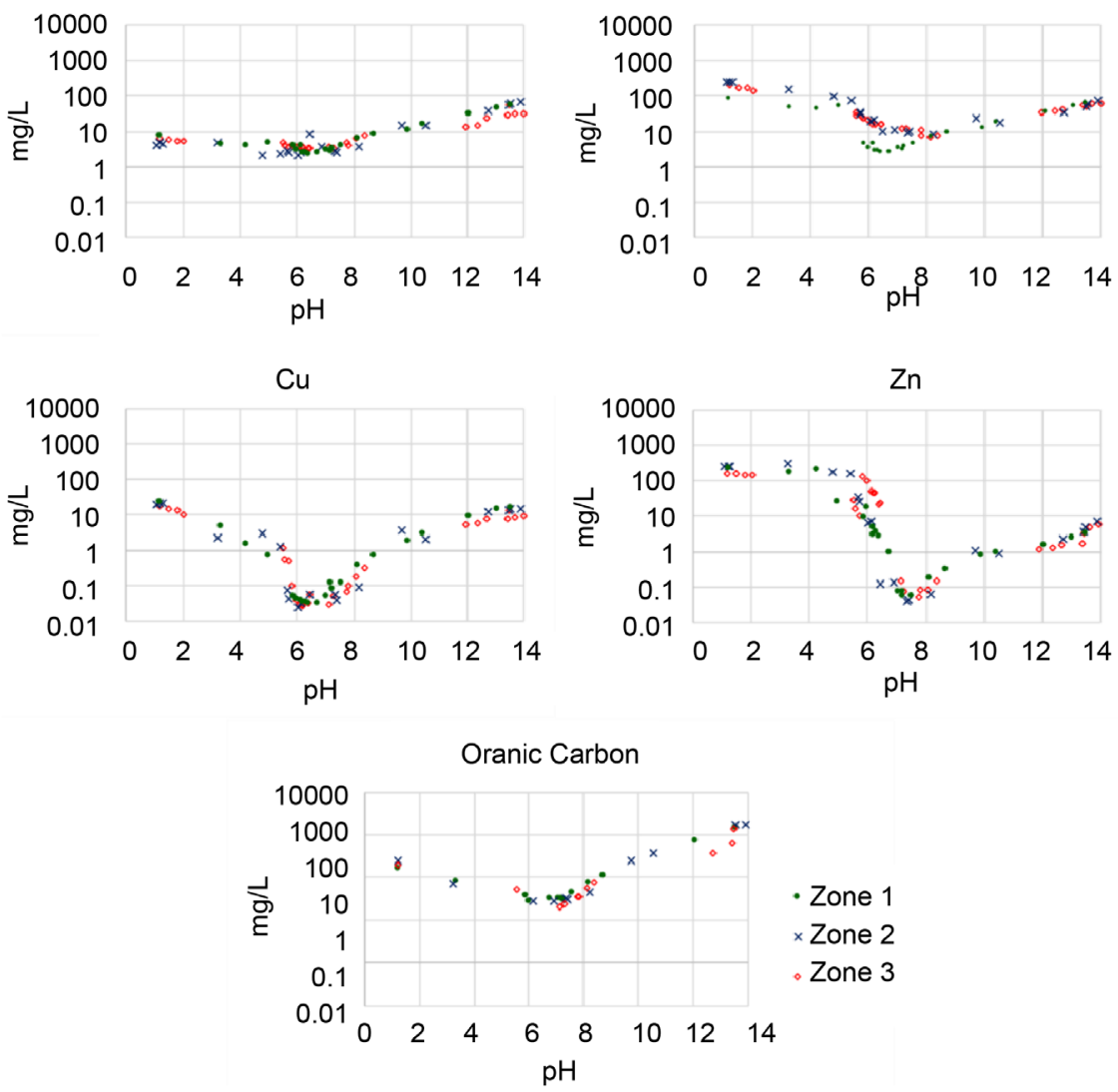

Figure 5. Major, trace and solubilized organic carbon release as a function of $\mathrm{pH}$ for the three zones collected in 2013.

of $>13.5$ versus 12.5 for 2015 . Regarding conductivity, the curves are also very similar, except the portion between $\mathrm{pH}=8$ and $\mathrm{pH}=9$ and a point at $\mathrm{pH}=12$ (Figure 4, Conductivity). Redox potential curves are similar at extreme $\mathrm{pH}$ values and around the neutral $\mathrm{pH}$ (between $\mathrm{pH}=4$ and $\mathrm{pH}=9$ ), with some discre- 
pancies for the other parts of the curves (Figure 4, Redox potential). It can be noted that some parts of the curves exhibit a significant scattering of the data, especially for the sample collected in 2015.

The solubility of major and trace elements is depicted in Figure 6 with the
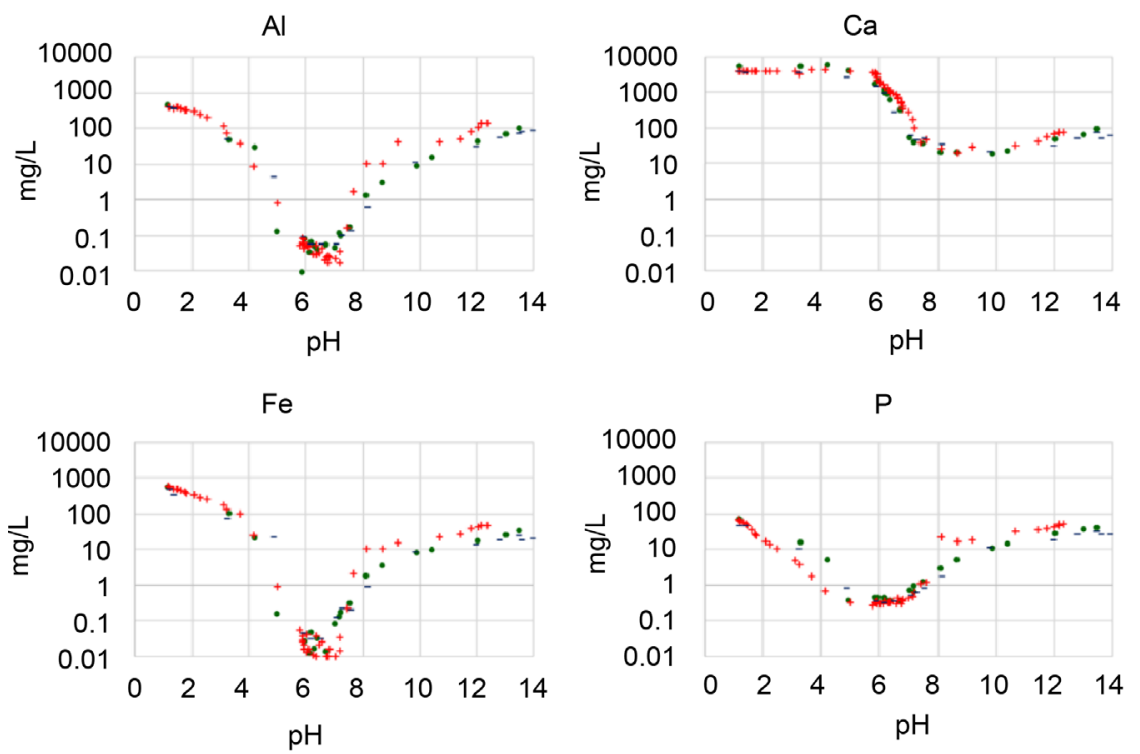

$\mathrm{S}$

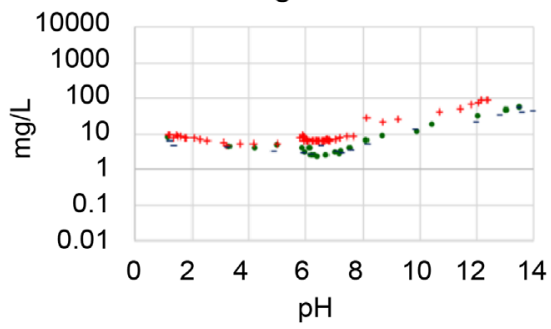

Si
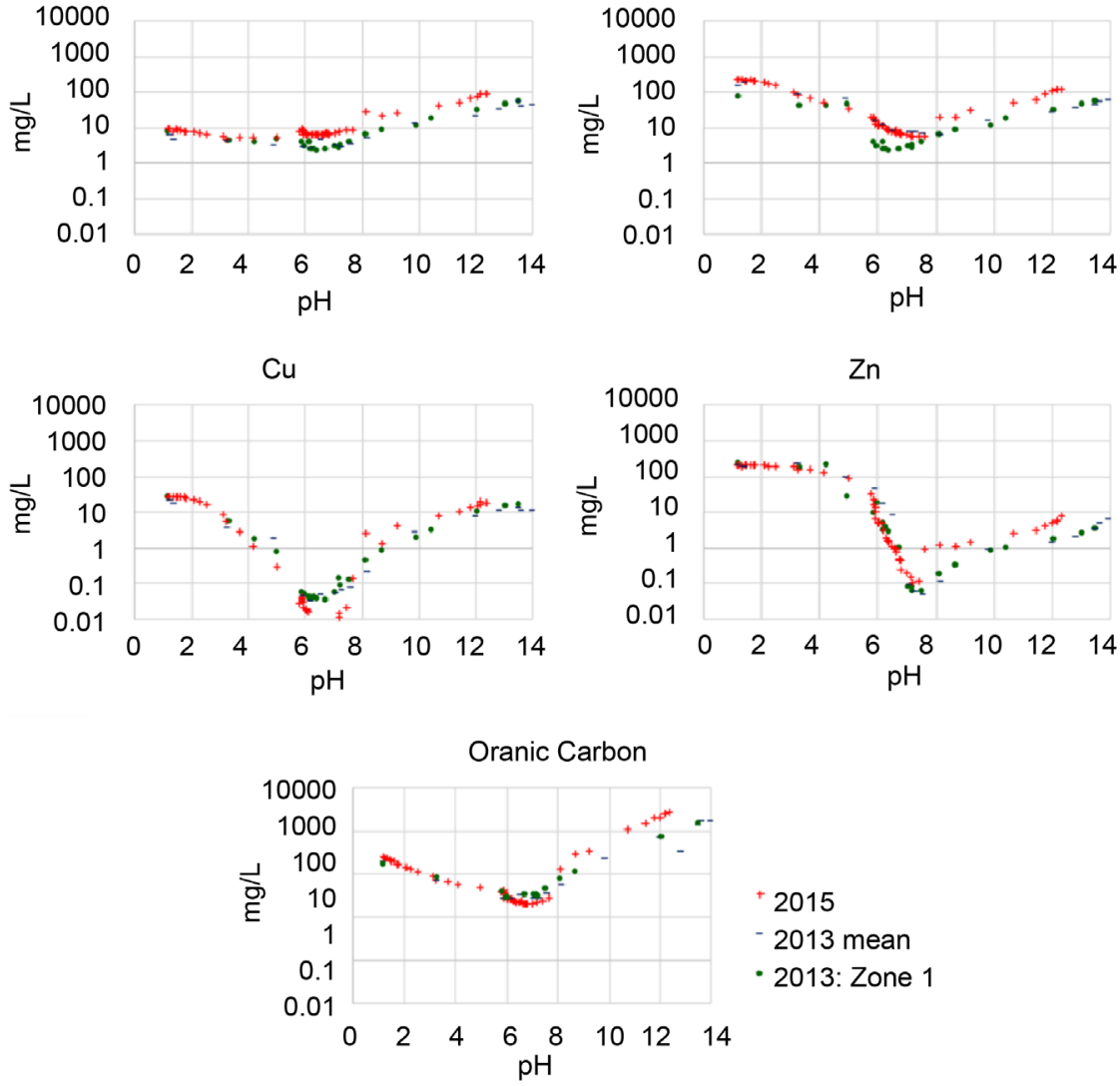

Figure 6. Major, trace and solubilized organic carbon release as a function of $\mathrm{pH}$ for (zone 1 and zone-averaged sample) and 2015 (zone 1). 
samples collected in 2013 (zone 1 and zone-averaged data) and 2015 (zone 1). Trends are very similar between 2013 and 2015 with in all cases, a bell-shaped curve for aluminum $(\mathrm{Al})$, iron $(\mathrm{Fe})$, copper $(\mathrm{Cu})$ and zinc $(\mathrm{Zn})$, (ii) a more stable solubility for phosphorus $(\mathrm{P})$, sulfur $(\mathrm{S})$, silicon $(\mathrm{Si})$ and organic carbon, and (iii) the particular S-shaped curve for calcium (Ca). However, the release in the basic range was slightly higher in 2015, excepted calcium with the similar release over the whole range of $\mathrm{pH}$. These data demonstrate that the date of sampling does not significantly affect the major and trace element release.

\subsection{Maximum Release of Major and Trace Elements under Extreme Conditions}

In addition to the previous data, the elementary release was computed in percentage for three specific cases: contact with pure water, extreme acidic and basic conditions (Table 3). Overall, for all elements except sulfur and silicon, the most important release is effective under acidic conditions (e.g. calcium with more than $43 \%$ released). Solubility is very low for neutral $\mathrm{pH}$ after addition of only pure water (less than $1 \%$ solubilized for most elements), whereas basic conditions also favor element solubilization, but to a lesser extent in comparison to extreme acidic conditions.

Under neutral $\mathrm{pH}$ conditions (contact with pure water), the calcium is the most mobile element $(0.14 \%)$, while aluminum and iron are the less mobile $(0.0005 \%)$. Under these $\mathrm{pH}$ conditions, trace elements (copper and zinc) are rather insoluble. However, under extremely acidic conditions, calcium and trace elements are proportionally the most mobile: with a release $>30 \%$ of the total content. Aluminum, iron, and phosphorus are leached in smaller proportions $(6 \%, 9 \%$ and $13 \%)$. Sulfur and silicon have the lowest mobility $(0.5 \%)$. Finally, in basic extreme conditions, elements are moderately mobile (less than $1 \%$ ), excepted phosphorus (3\%) and copper (5\%) attesting their amphoteric behavior.

Table 3. Mean proportion (\% of total content) of the maximum major and trace element release in the different extreme environment for sediments collected in the three zones in 2013.

\begin{tabular}{cccc}
\hline & Water & Acidic conditions & Basic conditions \\
\hline $\mathrm{Al}$ & 0.0003 & 6.23 & 0.47 \\
$\mathrm{Ca}$ & 0.14 & 43.06 & 0.16 \\
$\mathrm{Cu}$ & 0.02 & 38.12 & 4.93 \\
$\mathrm{Fe}$ & 0.0008 & 9.07 & 0.15 \\
$\mathrm{P}$ & 0.053 & 12.73 & 3.23 \\
$\mathrm{~S}$ & 0.046 & 0.35 & 0.70 \\
$\mathrm{Si}$ & 0.005 & 0.38 & 0.09 \\
$\mathrm{Zn}$ & 0.004 & 30.74 & 0.25 \\
\hline
\end{tabular}




\section{Discussion}

\subsection{Spatial Homogeneity of Major and Trace Element Solubilization}

The spatial variability, as revealed by the comparison between the samples collected in 2013, are successively discussed regarding buffer capacity and major element and trace element release. For all samples, the buffer capacity has a clear effect on $\mathrm{pH}$ (Figure 3, pH). The addition of acid does not change the value of redox potential, as far as $\mathrm{pH}$ remains above 4 (Figure 3, Redox potential), revealing the strong buffer capacity of samples. Below 4 , the increase in redox potential results probably from the addition of the nitric acid. Regarding $\mathrm{pH}$ as a function of added amount of $\mathrm{H}^{+}$, the same buffer capacity occurs. The addition of acid results in a stabilization of $\mathrm{pH}$ at a value of $\mathrm{pH}=6$, sharpening a plateau on curve $\mathrm{pH}=\mathrm{f}\left(\mathrm{eq}_{-} \mathrm{H}^{+}\right)$. The length of the plateau can be related to sediment buffer capacity, namely the amount of equivalent $\mathrm{H}^{+}$needed to counteract buffer capacity. This last is supposed to result from the high amounts of carbonates [13]. Consequently, the length of the plateau can be regarded as a good indicator of the amount of calcite for all samples. The high contents of calcite in the studied sediments results from the local geological context and the contribution of activities and buildings of the industrial catchment [16].

Despite similar patterns, there remain some discrepancies between the different samples. As indicated above, the lengths of the plateaus for the curve $\mathrm{pH}=$ $\mathrm{f}\left(\right.$ eq_ $\left.\mathrm{H}^{+}\right)$quantifies buffer capacities. Sorting samples by decreasing buffer capacities leads to zone $3>$ zone $1>$ zone 2 . Such order can be linked to the calcite content (Table 2). The difference of calcite content between samples may result from different deposition patterns or weathering conditions after deposition in relation with contrasting hydric conditions (some locations being more often ponded with water than others). The three samples are located at different zones corresponding to contrasting deposition mechanisms and evolution of sediment. Zone 2, that has the lowest calcite content, is the furthest point from the water entry in the basin. So, mineral particles could have settled earlier or been dissolved partly before reaching this zone. Moreover, this zone is the most organic one, suggesting a decrease of the mineral fraction in this area.

As for buffer capacity, the samples collected in 2013 exhibit similar trends for major elements release. Conductivity gives an insight on the bulk release of charged species. The evolution of conductivity is closely linked to element solubility. The highest values of element solubility are obtained for the conditions that favor the most element release, i.e. extreme $\mathrm{pH}$ values, and, in particular, the most acidic conditions (Table 3). The three samples are similar regarding not only conductivity but also element release. The elements can be sorted on the basis of their solubility curves as follows (Figure 5 and Table 3): i) very mobile elements with a strong release when adding acid (e.g. $\mathrm{Ca}, \mathrm{Cu}$, and $\mathrm{Zn}$ ), ii) elements with intermediate solubility (e.g. Al, Fe and P) and iii) elements that are not soluble and sensitive to $\mathrm{pH}$ conditions ( $\mathrm{S}$ and $\mathrm{Si}$ ). The strong mobility of 
calcium is related to the dissolution of calcite. The addition of acid allows a complete dissolution of calcite with the release of $100 \%$ of the initial calcium content. Note that $\mathrm{Cu}$ release under extreme basic conditions moves apart from $\mathrm{Zn}$ release (Figure 5, Cu) versus (Figure 5, $\mathrm{Zn}$ ), and Table 3 ), indicating probably a different speciation in the solid phase. Conversely, Si solubility remains normally very low like sulfur suggesting that these elements belong to phases that do not dissolve at all, probably silicate phases. The experimental results reveal the same pattern regardless the zone of sampling zone. However, some slight discrepancies remain. Solubility, overall, seems a little larger for the zone 3 when acid is added (Figure 5). This fact may result from its particular composition with higher amounts of hornblende and labradorite (Table 2). The higher solubility in terms of calcium and the stronger decrease observed between $\mathrm{pH}=$ 6 and $\mathrm{pH}=2$ (Figure 3 ) may result from a higher calcite content (Table 2).

\subsection{Temporal Variability on Leaching Elements}

The temporal stability is underlined by the similarity of the experimental results between the sediment sampled in 2015 and those sampled in 2013 (Figure 4 and Figure 6). Again, slight discrepancies remain between the samples. The asymptote in the basic range cannot reach a pH higher than 12.5 in 2015 whereas the asymptote obtained for 2013 is positioned at a $\mathrm{pH}$ higher than 13.5 (Figure 4, $\mathrm{pH}$ ). It can be noted that the conductivity curves fit perfectly (Figure 4, Conductivity). The reasons for the slight discrepancies were not clearly identified but may be the consequence of differences in mineral composition or the disappearance of some phases due to weathering during the 2 years that passed between 2013 and 2015. To understand these slight differences, it would be interesting to use geochemical modeling to get insight on mineral phase dissolution and related effects on $\mathrm{pH}$.

Despite the slight discrepancies discussed above, the experimental results show that all the samples collected in Django Reinhardt infiltration basins show similar reactivity. Spatial and temporal variability consequently do not play a significant role regarding element release. Spatial and temporal stability may appear surprising since the different zones of the infiltration basin may undergo different hydric conditions (water ponding versus drying/wetting cycles), which should impact weathering processes. Also, the quality of entering water may change with time depending on human activities and rainfall events. However, a drastic change in industrial activity is not expected in the catchment related to Django Reinhardt infiltration basin. At last, vegetation that colonizes the infiltration basin may play a significant role in the sediment geochemical characteristics. Despite all these sources of spatial and temporal variability, the results presented here tend to demonstrate that particles eroded from the urban watershed and entering the basin have already evolve chemically before settling and consequently present very stable mineral phases like insoluble natural minerals or non-soluble anthropic particles (mineral alloys for examples). Previous au- 
thors already made this conclusion after having identified several stable mineral phases in sediments from other stormwater infiltration basins [14].

\subsection{Correlations between Major and Trace Element Leaching and Organic Matter}

The study of the concomitant release of elements gives further insight on the potential phases constituting the studied solid samples. Figure 7 presents the linear regressions between trace elements, majors and organic matter concentrations obtained for all the samples. For some major elements, there are combinations but without any clear linearity: $\mathrm{Cu}=\mathrm{f}(\mathrm{Zn}, \mathrm{Ca}$, and $\mathrm{P}), \mathrm{Zn}=\mathrm{f}(\mathrm{Al}, \mathrm{Ca}$ and $\mathrm{Si}), \mathrm{Al}=\mathrm{f}(\mathrm{Ca}$ and $\mathrm{P}), \mathrm{Ca}=\mathrm{f}(\mathrm{Fe}, \mathrm{P}$ and $\mathrm{Si})$ and $\mathrm{P}=\mathrm{f}(\mathrm{Si})$.

We also note a simple linear relation between sulfur and organic carbon contents. It reveals a close link between sulfur release and solubilization of organic matter, whatever the $\mathrm{pH}$. Moreover, these graphics show that the leaching of $\mathrm{Al}$, $\mathrm{Fe}$, and $\mathrm{Si}$ are closely linked by simple linear combinations, suggesting a concomitant elution of these elements. Such pattern indicates the presence of one main phase containing aluminum, iron, and silicon, probably pointing at aluminosilicate. Given the composition of the studied matrices (Table 2), this phase is expected to be chamosite or/and hornblende.

For some couples of elements, a particular linear relation with two different slopes was observed. The two slopes were obtained by adding either the acid or the base and corresponding to acidic and basic conditions, respectively. Sulfur is an excellent example of such pattern regarding its relationship with all the other

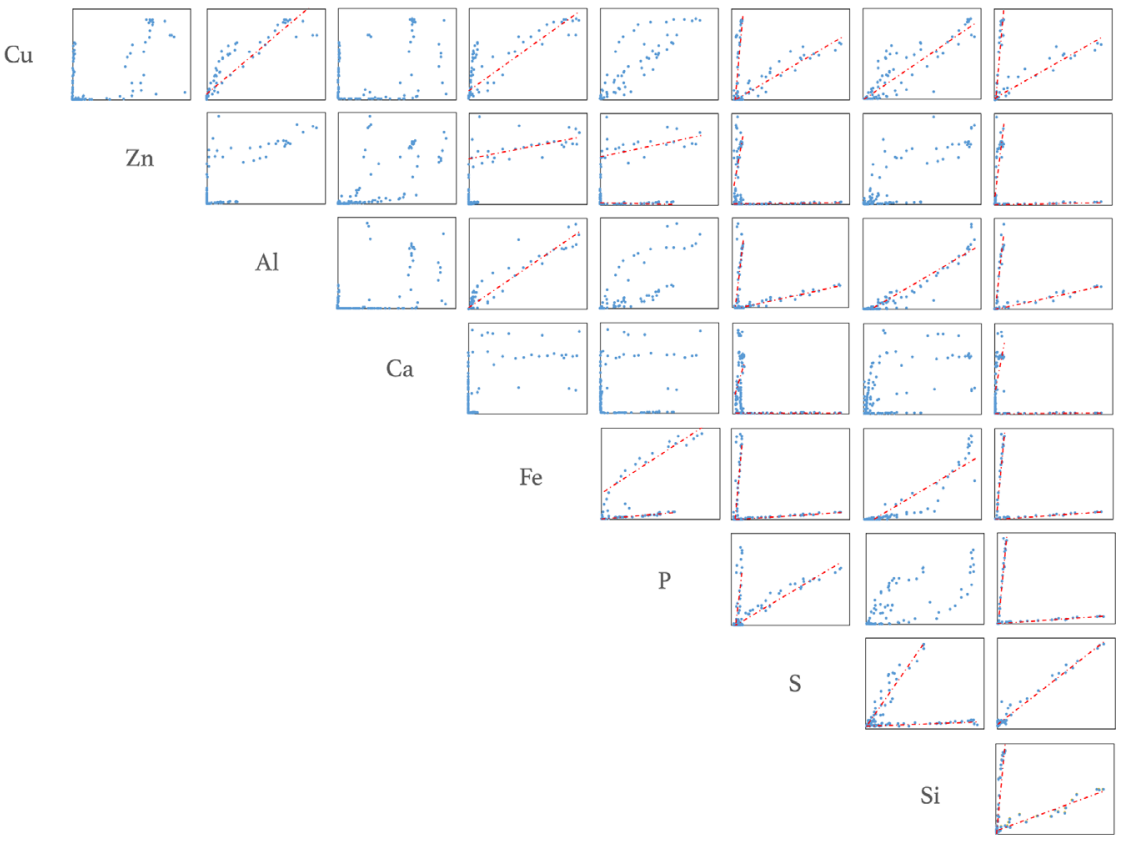

OC

Figure 7. Plots of co-release (concentrations in $\mathrm{M}$ ) for major and trace elements, and organic matter. 
elements (excepted organic matter). Such pattern may point at the dissolution of two different mineral phases depending on the $\mathrm{pH}$ range: one phase in the acidic range and another in the basic area. It can be noted that all element concentrations can be linked to organic matter with two different slopes. This is also the case for organic matter with all elements (excepting sulfur). Besides, calcium release seems independent of the other elements. Aluminum, iron and silicon coeluate quite often with high correlations between their concentrations. Organic matter appears to play a major role since the release of organic carbon is strongly correlated to the release of many elements.

\subsection{Trace Element Leaching: $\mathrm{Cu}$ and $\mathrm{Zn}$}

Overall, trace elements are of interest due to their potential toxicity as well as their permanence in the environment. In this study, the concentrations $\mathrm{Cu}$ and $\mathrm{Zn}$ exceeded the probable effect concentrations related to eco-toxicological effects (PEC; $\mathrm{Zn}=459 \mathrm{ppm}, \mathrm{Cu}=149 \mathrm{ppm}$ ) [32]. Copper and zinc are not very mobile in the $\mathrm{pH}$ range of "natural" water $(0.02 \%$ and $0.004 \%$ respectively). However, they are more soluble in extreme $\mathrm{pH}(38.12 \%$ and $30.74 \%$ respectively in acidic area).

As regards to the leaching of copper in the studied sediments, Table 4 emphasizes a copper mobility associated linearly with aluminum, iron, and silicon. Thus, copper is mainly released by the dissolution of aluminosilicate (chamosite). There is also a double linear association between copper and sulfur, on the one hand, and organic carbon, on the other hand. This result highlights the strong interactions that are widely described between copper and OM in soils and sediments [13]. Different sequential extraction studies have demonstrated the presence of copper mainly in the following compartments: residual fraction $>$ bound to Fe-Mn oxides $>$ bound to organic matter $>$ bound to carbonates [14] [33] [34] [35]. In those studies, there are few amounts of leached copper. These results are consistent with our results and show that copper is associated with very stable mineral phases as well as organic matter.

Zinc exhibits double linear associations with sulfur, phosphorus and organic carbon (revealing links with organic matter). There is also a simple linear combination with iron. The literature shows that zinc is predominately bound to the following compartments: residual fraction $>$ Fe-Mn oxides $>$ carbonates $>$ organic material $>$ cationic exchange sites [36]. These results are also consistent with the correlations identified by the ANC-BNC titration and highlight the links between zinc and iron oxides and organic matter. The difference in mobility of $\mathrm{Zn}$ and $\mathrm{Cu}$ under basic conditions can be directly related to the combination of a fraction of copper with humic acid or phases that are soluble in acid conditions in opposite to fulvic acids.

\section{Conclusions}

This study highlights the value of the information obtained with the Acid Neutralization Capacity-Basic Neutralization Capacity titration on geochemical 
Table 4. linear relations between element concentrations.

\begin{tabular}{|c|c|c|c|c|c|c|c|}
\hline$[\mathrm{X}]$ & {$[\mathrm{Y}]$} & Eq. & $\mathbf{R}^{2}$ & {$[\mathrm{X}]$} & {$[\mathrm{Y}]$} & Eq. & $\mathbf{R}^{2}$ \\
\hline $\mathrm{Al}$ & $\mathrm{Cu}$ & $\mathrm{Cu}=0.0549^{\star} \mathrm{Al}+1.9577$ & 0.82898 & \multirow{2}{*}{$\mathrm{s}$} & \multirow{2}{*}{$\mathrm{Ca}$} & $\mathrm{Ca}=264.94^{*} \mathrm{~S}+758.26$ & 0.12111 \\
\hline $\mathrm{Fe}$ & $\mathrm{Cu}$ & $\mathrm{Cu}=0.0462^{\star} \mathrm{Fe}+3.0162$ & 0.698 & & & $\mathrm{Ca}=0.02045^{\star} \mathrm{S}+49.986$ & 0.02045 \\
\hline \multirow{2}{*}{$\mathrm{S}$} & \multirow{2}{*}{$\mathrm{Cu}$} & $\mathrm{Cu}=4.2905^{\star} \mathrm{S}-12.919$ & 0.77497 & \multirow{2}{*}{ OC } & \multirow{2}{*}{$\mathrm{Ca}$} & $\mathrm{Ca}=13.537^{\star} \mathrm{OC}+1381.2$ & 0.4228 \\
\hline & & $\mathrm{Cu}=0.2294^{\star} \mathrm{S}-0.90891$ & 0.90891 & & & $\mathrm{Ca}=0.0111^{\star} \mathrm{OC}+44.431$ & 0.21275 \\
\hline $\mathrm{Si}$ & $\mathrm{Cu}$ & $\mathrm{Cu}=0.1066^{\star} \mathrm{Si}+0.027$ & 0.78778 & \multirow{2}{*}{$\mathrm{P}$} & \multirow{2}{*}{$\mathrm{Fe}$} & $\mathrm{Fe}=6.3611^{\star} \mathrm{P}+171.12$ & 0.91148 \\
\hline \multirow{2}{*}{ OC } & \multirow{2}{*}{$\mathrm{Cu}$} & $\mathrm{Cu}=0.1442^{\star} \mathrm{OC}-5.1323$ & 0.90036 & & & $\mathrm{Fe}=0.8512^{\star} \mathrm{P}+2.4893$ & 0.45821 \\
\hline & & $\mathrm{Cu}=0.0074^{\star} \mathrm{OC}+0.4398$ & 0.92889 & \multirow{2}{*}{ S } & \multirow{2}{*}{$\mathrm{Fe}$} & $\mathrm{Fe}=80.093^{*} \mathrm{~S}-237.37$ & 0.75327 \\
\hline $\mathrm{Fe}$ & $\mathrm{Zn}$ & $\mathrm{Zn}=0.129^{\star} \mathrm{Fe}+149.55$ & 0.31691 & & & $\mathrm{Fe}=0.5181^{\star} \mathrm{S}-2.0896$ & 0.92043 \\
\hline \multirow{2}{*}{$\mathrm{P}$} & \multirow{2}{*}{$\mathrm{Zn}$} & $\mathrm{Zn}=1.0107^{\star} \mathrm{P}+158.53$ & 0.26824 & Si & $\mathrm{Fe}$ & $\mathrm{Fe}=1.8597^{\star} \mathrm{Si}-38.059$ & 0.83426 \\
\hline & & $\mathrm{Zn}=-0.0933^{\star} \mathrm{P}+6.7189$ & 0.0174 & \multirow{2}{*}{$\mathrm{OC}$} & \multirow{2}{*}{$\mathrm{Fe}$} & $\mathrm{Fe}=2745^{\star} \mathrm{OC}-85.12$ & 0.92721 \\
\hline \multirow{2}{*}{$\mathrm{S}$} & \multirow{2}{*}{$\mathrm{Zn}$} & $\mathrm{Zn}=22.173^{\star} \mathrm{S}+15.764$ & 0.30233 & & & $\mathrm{Fe}=0.0177^{\star} \mathrm{OC}-0.4232$ & 0.96422 \\
\hline & & $\mathrm{Zn}=0.0294^{\star} \mathrm{S}+2.5157$ & 0.02015 & \multirow{2}{*}{$S$} & \multirow{2}{*}{$\mathrm{P}$} & $\mathrm{P}=8.4482^{\star} \mathrm{S}-30.666$ & 0.61097 \\
\hline \multirow{2}{*}{$\mathrm{OC}$} & \multirow{2}{*}{$\mathrm{Zn}$} & $\mathrm{Zn}=1.0461^{\star} \mathrm{OC}+7.1905$ & 0.6909 & & & $\mathrm{P}=0.61406^{\star} \mathrm{S}-2.0713$ & 0.95697 \\
\hline & & $\mathrm{Zn}=0.0024^{*} \mathrm{OC}+0.2356$ & 0.92385 & \multirow{2}{*}{ OC } & \multirow{2}{*}{$\mathrm{P}$} & $\mathrm{P}=2.745^{\star} \mathrm{OC}-85.12$ & 0.92721 \\
\hline $\mathrm{Fe}$ & $\mathrm{Al}$ & $\mathrm{Al}=0.8816^{\star} \mathrm{Fe}+14.681$ & 0.9134 & & & $\mathrm{P}=0.0177^{\star} \mathrm{OC}+0.4232$ & 0.96422 \\
\hline \multirow{2}{*}{ S } & \multirow{2}{*}{$\mathrm{Al}$} & $\mathrm{Al}=67.025^{\star} \mathrm{S}-176.73$ & 0.62745 & \multirow{2}{*}{$\mathrm{Si}$} & \multirow{2}{*}{ S } & $S=0.7569^{\star} S i+1.436$ & 0.9087 \\
\hline & & $\mathrm{Al}=1.6833 * \mathrm{~S}-9.3543$ & 0.94019 & & & $S=0.018^{\star} S i+3.3439$ & 0.63136 \\
\hline $\mathrm{Si}$ & $\mathrm{Al}$ & $\mathrm{Al}=1.8145^{\star} \mathrm{Si}-28.783$ & 0.91528 & OC & $S$ & $\mathrm{~S}=0.0336^{\star} \mathrm{OC}+4.9172$ & 0.97149 \\
\hline \multirow{2}{*}{ OC } & \multirow{2}{*}{$\mathrm{Al}$} & $\mathrm{Al}=2.3828^{\star} \mathrm{OC}-77.527$ & 0.85532 & \multirow{2}{*}{ OC } & \multirow{2}{*}{$\mathrm{Si}$} & $\mathrm{Si}=1.1901^{\star} \mathrm{OC}-20.957$ & 0.926 \\
\hline & & $\mathrm{Al}=0.0564^{\star} \mathrm{OC}-0.6527$ & 0.96056 & & & $\mathrm{Si}=0.0403^{\star} \mathrm{OC}+9.7834$ & 0.91269 \\
\hline
\end{tabular}

properties of urban sediments. Indeed, this study shows that similar results were obtained for different ANC-BNC tests performed on various sediment samples collected at different periods and different places of the same infiltration basin. These results suggest that the sampling of sediments at one single place and date is enough to get a proper insight on major and trace metal release. Obviously, this study shows the uniformity of the geochemical properties of the sediment despite varying operation conditions of infiltration basins. Besides, the particles produced are very stable and specific of urban signature. Such pattern facilitates the generalization of measured properties of ANC-BNC tests. Such result is of importance regarding the management of these sediments in infiltration basins or after dredging. This result highlights the importance of controlling sources of urban particles constituting the deposited sediments.

As the properties of urban sediments appear very stable, it is possible and appropriate to develop geochemical models in association with ANC-BNC titrations. This would provide a model of sediment leaching properties and allow the calculation of solubility and speciation of elements in various geochemical situations. Overall, modeling can be developed and used to provide useful information for environmental assessments of various scenarios in the framework of ur- 
ban sediments management and in stormwater infiltration management, which is the topic of ongoing research.

\section{Acknowledgements}

The authors would like to thank Nathalie Dumont and David Lebouil (DEEP) and Myriam Hammada (LEHNA) for technical assistance and analytical analyses. The authors are grateful to the Research and Service Unit in Mineral Technology (Unité de Recherche et de Service en Technologie Minérale (URSTM)), the University of Quebec in Abitibi-Temiscamingue (UQAT) for the experimental support. The authors are grateful to the field observatory for urban water management (OTHU) and CNRS EC2CO for their logistic and financial support. Sarah Hammecker, a certified French-to-English translator, was responsible for proofreading this text

\section{References}

[1] Mikkelsen, P.S., Hafliger, M., Ochs, M., Jacobsen, P., Tjell, J.C. and Boller, M. (1997) Pollution of Soil and Groundwater from Infiltration of Highly Contaminated Stormwater-A Case Study. Water Science and Technology, 36, 325-330.

[2] Winiarski, T., Bedell, J.-P., Delolme, C. and Perrodin, Y. (2006) The Impact of Stormwater on a Soil Profile in an Infiltration Basin. Hydrogeology Journal, 14, 1244-1251. https://doi.org/10.1007/s10040-006-0073-9

[3] Lassabatere, L., Angulo-Jaramillo, R., Goutaland, D., Letellier, L., Gaudet, J., Winiarski, T., et al. (2010) Effect of the Settlement of Sediments on Water Infiltration in Two Urban Infiltration Basins. Geoderma, 156, 316-325. https://doi.org/10.1016/j.geoderma.2010.02.031

[4] Pettersson, T.J.R., German, J. and Svensson, G. (1999) Pollutant Removal Efficiency in Two Stormwater Ponds in Sweden. Doktorsavhandlingar vid Chalmers Tekniska Hogskola, 1542, 866-873.

[5] Bäckström, M. (2002) Sediment Transport in Grassed Swales during Simulated Runoff Events. Water Science and Technology, 45, 41-49.

[6] Färm, C. (2002) Evaluation of the Accumulation of Sediment and Heavy Metals in a Storm-Water Detention Pond. Water Science and Technology, 45, 105-112.

[7] Durand, C. (2003) Caractérisation physico-chimique des produits de l'assainissement pluvial: origine et devenir des métaux traces et des pollutants organiques, Poitiers, 2003.

[8] Badin, A.-L., Bedell, J.-P. and Delolme, C. (2009) Effect of Water Content on Aggregation and Contaminant Leaching: The Study of an Urban Technosol. Journal of Soils and Sediments, 9, 653-663. https://doi.org/10.1007/s11368-009-0128-3

[9] Larmet, H. (2007) Mobilisation et transfert de $\mathrm{Zn}, \mathrm{Cd}$, cu et des colloïdes bactériensdans les basins d'infiltration d'eaux pluviales: influence des conditions hydrodynamiques, Université Joseph-Fourier-Grenoble I, 2007.

[10] El-Mufleh, A., Béchet, B., Ruban, V., Legret, M., Clozel, B., Barraud, S., et al. (2014) Review on Physical and Chemical Characterizations of Contaminated Sediments from Urban Stormwater Infiltration Basins within the Framework of the French Observatory for Urban Hydrology (SOERE URBIS). Environmental Science and Pollution Research, 21, 5329-5346. https://doi.org/10.1007/s11356-013-2490-3 
[11] Gao, L., Chen, J., Tang, C., Ke, Z., Wang, J., Shimizu, Y., et al. (2015) Distribution, Migration and Potential Risk of Heavy Metals in the Shima River Catchment Area, South China. Environmental Science: Processes \& Impacts, 17, 1769-1782. https://doi.org/10.1039/C5EM00156K

[12] Izquierdo, M., Tye, A.M. and Chenery, S.R. (2013) Lability, Solubility and Speciation of $\mathrm{Cd}, \mathrm{Pb}$ and $\mathrm{Zn}$ in Alluvial Soils of the River Trent Catchment UK. Environmental Science: Processes \& Impacts, 15, 1844-1858. https://doi.org/10.1039/c3em00370a

[13] El-Mufleh, A., Béchet, B., Ruban, V., Legret, M., Clozel, B., Barraud, S., et al. (2014) Review on Physical and Chemical Characterizations of Contaminated Sediments from Urban Stormwater Infiltration Basins within the Framework of the French Observatory for Urban Hydrology (SOERE URBIS). Environmental Science and Pollution Research, 21, 5329-5346. https://doi.org/10.1007/s11356-013-2490-3

[14] Clozel, B., Ruban, V., Durand, C., and Conil, P. (2006) Origin and Mobility of Heavy Metals in Contaminated Sediments from Retention and Infiltration Ponds. Applied Geochemistry, 21, 18. https://doi.org/10.1016/j.apgeochem.2006.06.017

[15] Durin, B. (2006) Transfert et transport colloïdal de polluantsmétalliques-Applications en assainissement routier, 2006.

[16] Saulais, M. (2011) Colonisation végétale des basins d'infiltration et de retention : Caractérisation de la flore et évolution des caractéristiques physico-chimiques de l'horizon de surface végétalisé, INSA de Lyon, 2011.

[17] Claff, S.R., Sullivan, L.A., Burton, E.D. and Bush, R.T. (2010) A Sequential Extraction Procedure for Acid Sulfate Soils: Partitioning of Iron. Geoderma, 155, 224-230. https://doi.org/10.1016/j.geoderma.2009.12.002

[18] Golterman, H., Paing, J., Serrano, L. and Gomez, E. (1997) Presence of and Phosphate Release from Polyphosphates or Phytate Phosphate in Lake Sediments. Hydrobiologia, 364, 99-104. https://doi.org/10.1023/A:1003212908511

[19] Chuan, M., Shu, G. and Liu, J. (1996) Solubility of Heavy Metals in a Contaminated Soil: Effects of Redox Potential and pH. Water, Air, \& Soil Pollution, 90, 543-556. https://doi.org/10.1007/BF00282668

[20] Blanchard, C., Moszkowicz, P. and Sanchez, F. (2000) Caractérisation de la mobilisation potentielle des polluantsin organiques dans les sols pollutes : Approche méthodologique. Déchets Sciences \& Techniques, 20, 33-40.

[21] Peyronnard, O., Blanc, D., Benzaazoua, M. and Moszkowicz, P. (2009) Study of Mineralogy and Leaching Behavior of Stabilizaed/Solidified Sludge using Differential Acid Neutraization Analysis Part II : Use of Numerical Simulation as an Aid Tool for Cementitious Hydrates Identification. Cement and Concrete Research, 39, 9. https://doi.org/10.1016/j.cemconres.2009.03.016

[22] Glass, G.K. and Buenfeld, N.R. (1999) Differential Acid Neutralisation Analysis. Cement and Concrete Research, 29, 1681-1684. https://doi.org/10.1016/S0008-8846(99)00127-1

[23] Chatain, V., Blanc, D., Borschnek, D. and Delolme, C. (2013). Determining the Experimental Leachability of Copper, Lead, and Zinc in a Harbor Sediment and Modeling. Environmental Science and Pollution Research, 20, 66-74.

[24] Bisone, S., Gautier, M., Chatain, V. and Blanc, D. (2017) Spatial Distribution and Leaching Behavior of Pollutants from Phosphogypsum Stocked in a Gypstack. Geochemical Characterization and Modeling, 193, 567-575.

[25] Winiarski, T., Lassabatere, L., Angulo-Jaramillo, R. and Goutaland D. (2013) Characterization of the Heterogeneous Flow and Pollutant Transfer in the Unsaturated 
Zone in the Fluvio-Glacial Deposit. Procedia Environmental Sciences, 19, 955-964.

[26] Goutaland, D., Winiarski, T., Lassabatere, L., Dubé, J.S. and Angulo-Jaramillo, R. (2013) Sedimentary and Hydraulic Characterization of a Heterogeneous Glaciofluvial Deposit: Application to the Modeling of Unsaturated Flow. Engineering Geology, 166, 127-139. https://doi.org/10.1016/j.enggeo.2013.09.006

[27] Gonzalez-Merchan, C., Barraud, S. and Bedell, J.-P. (2014) Influence of Spontaneous Vegetation in Stormwater Infiltration System Clogging. Environmental Science and Pollution Research, 21, 5419-5426. https://doi.org/10.1007/s11356-013-2398-y

[28] Barraud, S. (2000) L'observatoire de terrain en hydrologie urbaine (OTHU) : Le cas de l'observation de l'infiltration des eaux de ruissellement. In: Infiltration Eaux Pluviales Journ, Tech.

[29] AFNOR (2015) NF EN 14429 Caractérisation des déchets Essais de comportement à la lixiviation-Influence du $\mathrm{pH}$ sur la lixiviation avec ajout initial d'acide/base.

[30] Goutaland, D., Winiarski, T., Dubé, J.-S., Bièvre, G., Buoncristiani, J.-F., Chouteau, M., et al. (2008) Hydrostratigraphic Characterization of Glaciofluvial Deposits Underlying an Infiltration Basin using Ground Penetrating Radar. Vadose Zone Journal, 7, 194-207. https://doi.org/10.2136/vzj2007.0003

[31] Saulais, M., Bedell, J.-P. and Delolme, C. (2011) Cd, Cu and Zn Mobility in Contaminated Sediments from an Infiltration Basin Colonized by Wild Plants: The Case of Phalarisarundinacea and Typhalatifolia. Water Science and Technology, 64, 255-262. https://doi.org/10.2166/wst.2011.161

[32] MacDonald, D.D., Ingersoll, C.G. and Berger, T. (2000) Development and Evaluation of Consensus-Based Sediment Quality Guidelines for Freshwater Ecosystems. Archives of Environmental Contamination and Toxicology, 39, 20-31. https://doi.org/10.1007/s002440010075

[33] Morera, M., Echeverria, J., Mazkiaran, C. and Garrido, J. (2001) Isotherms and Sequential Extraction Procedures for Evaluating Sorption and Distribution of Heavy Metals in Soils. Environmental Pollution, 113, 135-144. https://doi.org/10.1016/S0269-7491(00)00169-X

[34] Isaure, M.-P., Laboudigue, A., Manceau, A., Sarret, G., Tiffreau, C., Trocellier, P., et al. (2002) Quantitative Zn Speciation in a Contaminated Dredged Sediment by $\mu$-PIXE, $\mu$-SXRF, EXAFS Spectroscopy and Principal Component Analysis. Geochimicaet Cosmochimica Acta, 66, 1549-1567. https://doi.org/10.1016/S0016-7037(01)00875-4

[35] Chaminda, G.T., Nakajima, F., Furumai, H., Kasuga, I. and Kurisu, F. (2010) Comparison of Metal ( $\mathrm{Zn}$ and $\mathrm{Cu}$ ) Complexation Characteristics of DOM in Urban $\mathrm{Ru}$ noff, Domestic Wastewater and Secondary Effluent. Water Science and Technology, 62, 2044-2050. https://doi.org/10.2166/wst.2010.517

[36] Zuo, X., Fu, D. and Li, H. (2012) Speciation Distribution and Mass Balance of Copper and Zinc in Urban Rain, Sediments, and Road Runoff. Environmental Science and Pollution Research, 19, 4042-4048. https://doi.org/10.1007/s11356-012-0907-z 